\title{
Design and Structural Analysis of Three Component Strain Gauge Balance
}

\author{
Guru Sankar Duppada ${ }^{1}$, Nikhil Nalamasu ${ }^{1}$, Naga Saikiranmai Aduri ${ }^{1}$, Navya Arisetty ${ }^{1}$, \\ Ramakrishna Madhira ${ }^{2}$, Suresh Kumar $C^{3}$ \\ ${ }^{1} U G$ Scholar, Department of Aeronautical Engineering, Bharath Institute of Higher Education \& Research, Chennai-600073, India. \\ ${ }^{2}$ Assistant Professor, Department of Aeronautical Engineering, Bharath Institute of Higher Education \& Research, Chennai-600073, India. \\ ${ }^{3}$ Associate Professor, Department of Aeronautical Engineering, Bharath Institute of Higher Education \& Research, Chennai-600073, India.
}

\begin{abstract}
Strain gauge balances are used to measure the aerodynamic forces that are acting on a scaled models or prototypes of different aerodynamic shapes. In this competitive world, to evaluate the relaibility of the structure a costless attempt is made by simulating (Ansys) the balance under various conditions and forces. Three component internal strain gauge balance is confined with the measurement of lift, drag and pitching moment. The loads that are acting on the body is measured in the form of strain by strain gauges. This paper provides the information related to the installation of strain gauges, design of beam according to the wind tunnel dimensions, and analyzing the structure by simulation of the beam with two different materials. The results are thus compared with the theoritical results that are calculated.
\end{abstract}

Keywords - Drag, Lift, Pitching moment, Proto-type Strain gauge, Strain gauge balance, Wind tunnel

\section{Review of Literature}

Mssrigrarom@ntu.edu.sg The principe that is used in the strain gauge balances is bending-beam principle. The forces acting on the balance causes strain on its surface, which will be measured by the strain gauges.

Ribeiro et al. The strain gauges are attached in wheatstone bridge configuration in which the change in strain will cause the change in resistance of the resistance and can be measured with data acquision system.

Bokai Liu et al. In order to simulate the performance of the aircraft beter, we need to simulate the aircraft in a wind tunnel. Current internal strain gauge balances are mounted inside the model that causes a change in the structure. So the structure can be mounted at the tail of the structure. So it can also make ease for calculating the torque.

Y.-J.Shi et al. The strain due to the axial forces is very small. To measure the axial forces thwart $1 \mathrm{t}$ beam is made and was improved using the optimation with FEA software. The beam reduces the $\mathrm{Y}$-interaction on $\mathrm{X}$ availability, benifiting the stability improvement of axial force.

Marco Scipioni et al. Internal balances vary in size and load carrying capacity, but in general they can be briefly categorized either by Force and moment balances
J.W.Hou et al. Elastic beam theory beam deformation is the result of two components, internal shear force and bending moment. The largest contributor to deformation in an elastic beam is due to bending, when the ratio of beam length to beam depth (L/D) is very large, i.e greater than 10:1. The deformation effects due to shear will be negliable and if the beam length to beam depth (L/D) is less than 10:1, then the Timoshenko Beam Theory (TBT) provides a more accurate results of deformation.

\section{INTRODUCTION}

Internal Strain gauge balance can be used most frequently in a stand to calibrate the aerodynamic forces and moments on a test model (in a test section). An important thing of a balance to be used is monitoring and extracting the forces and moments with less efforts. Either the flow may be steady or fluctuating, it is possible to extract the required results to evaluate the loads on the model, using stain gauge balances. These balance types are generally differentiated based on the number of force/moment that are extracted using the balance and the way the balance is being mounted. If they are mounted inside the model they are referred as internal balances and if they are mounted outside of the model or the wint tunnel they are referred as external balances. Here we consider internal strain gauge balances.

Generally the coordinate system is formed in the wind tunnel to evaluate the flow direction and forces. In normal, lift is defined as the force vertical or perpendicular to the flow direction, whereas the drag is termed as the force in the direction of the flow. Pitching moment is considered with the force that tends the body to the right of y axis. As we designed the structure to be three component internal strain gauge balance, it is confined to only lift (normal force), drag (axial force) and the pitching moment.

\begin{tabular}{|c|c|}
\hline Axis system & component \\
\hline $\mathrm{X}$ axis & Drag or axial force \\
\hline Y axis & Lift or normal force \\
\hline $\mathrm{Z}$ axis & Pitching moment \\
\hline
\end{tabular}




\subsection{Strain gauge}

Strain gauge are the sensors based on electrical resistance which generates a variation in its electrical resistance when subjected to an external force/deformation in its length. It is used to measure strain on a object.

\subsection{Purpose}

It is very challenging to evaluate the results from the tested aerodynamic model in the wind-tunnel. Although we got the readings we are not sure about the accuracy. The costliest phase of production is testing.

The emphasis made to design and analyze a three component internal strain gauge balance is to measure the forces and moment of an aerodynamic model mounted in the windtunnel. The beam calibrates lift, drag and pitching moment due to fluctuations in the fluid flow over a model. To maintain the cost efficiency designed beam is simulated and the results are analyzed

\section{2 .MATERIALS AND PROPERTIES USED}

1. Aluminium

$>$ Youngs modulus $=71.1 \mathrm{Gpa}$

$>$ Poissons ratio $=0.3$

$>$ Shear modulus $=2.4 * 10^{10} \mathrm{~N} / \mathrm{m}^{2}$

2. Steel

$>$ youngs modulus $-210 \mathrm{Gpa}$

$>$ Poissons ratio $=0.3$

$>$ Shear modulus $=7.2 * 10^{10} \mathrm{~N} / \mathrm{m}^{2}$

\section{STAGES OF WORK}

1. Design of beam

2. Uni-directional loading

2.1. When beam is subjected to lift

2.2. When beam is subjected to drag

2.3. When beam is subjected to pitching moment

3. Bi-directional loading

3.1. When beam is subjected to lift and drag

3.2. When beam is subjected to lift and pitching moment

3.3. When beam is subjected to drag and pitching moment

4. Tri-directional loading

4.1. When subjected to lift, drag and pitching moment

\subsection{Design of beam}

3 component internal strain gauge balance is to measure lift, drag and pitching moment. The beams is designed by refereeing various journals and previous work.

\subsubsection{Design Parameters}

$>$ Selected cantilever beam with a circular cross section of Dia $1.5 \mathrm{~cm}$ and length $30 \mathrm{~cm}$ and there will be two square sections with $\mathbf{8 m m}$ side. By mounting the beam in wind tunnel, fixing it to the model and allow the flow then we can measure the aerodynamic forces such as lift, drag and pitching moment through the strain Gauge attached to the beam's square portion.

$>$ Incentive of circular cross section of a beam is to extract the pitching moment value. The screws on the beam is to mount the models. The strain gauges are attached on the square or rectangular cross sections rather than circular section due to circumvent the more errors and extract nearly exact results and also to avoid more percent of error with strain gauges.

$>$ The wires will be connect to the beam directly passed to DAQ. To extract the results and to avoid maximum errors in calculations.

$>$ Beam is designed to withhold minimum load of 100 grams and it can be capable of extracting the required forces for any Aerodynamic model.

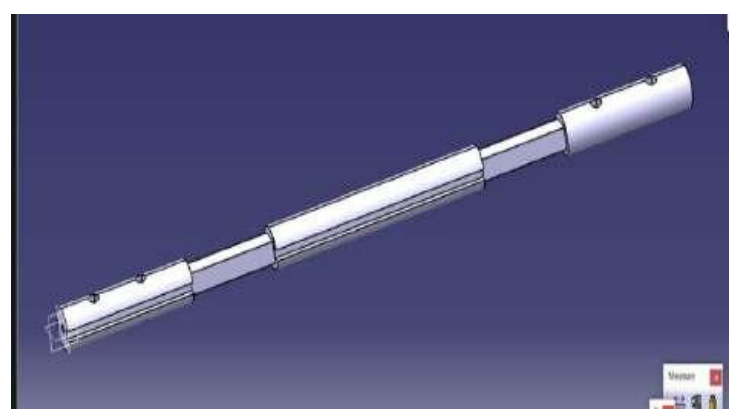

Fig 1 Design of beam in catia

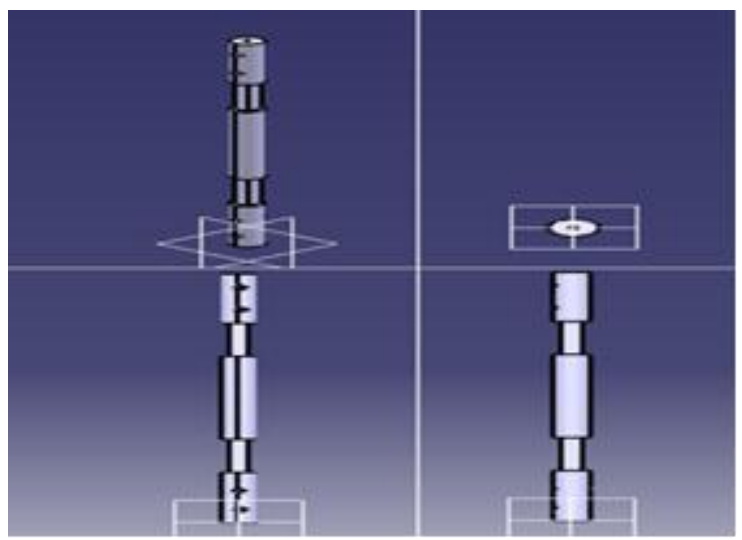

Fig 2 Three view diagram of beam 


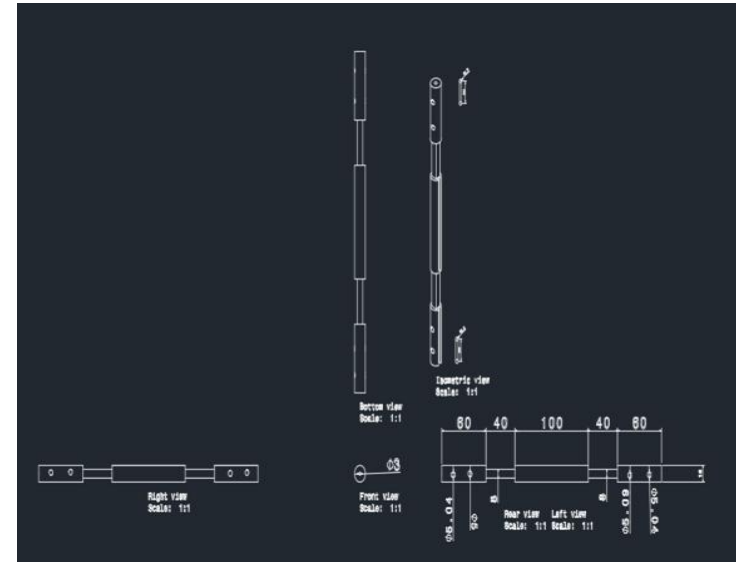

Fig 3 Design of beam with dimensions

\section{Structural Analysis}

Beam is subjected to various loads, forces and moments to evaluate the strength of the beam. It is tested with two different materials aluminium and steel. Theoritical results are also calculated along with the simulation results to get a comparision.

\section{SIMULATION RESULTS}

\section{UNI DIRECTIONAL LOADING OF BEAM}

\subsection{When subjected to only lift force}

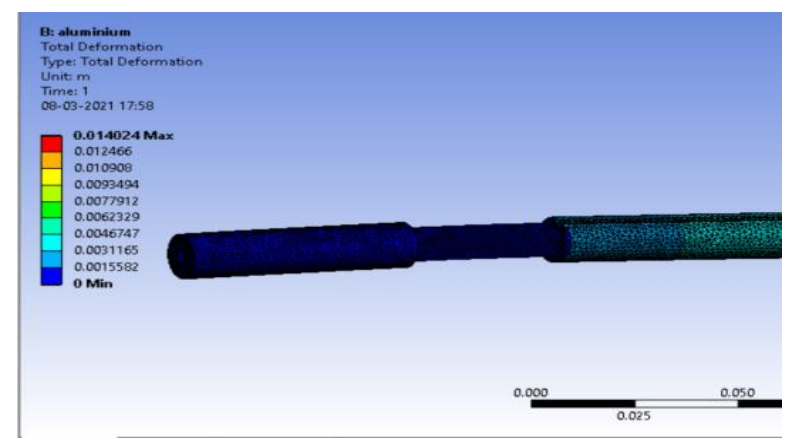

Fig 4 Aluminum beam subjected to $100 \mathrm{~N}$ lift at free end

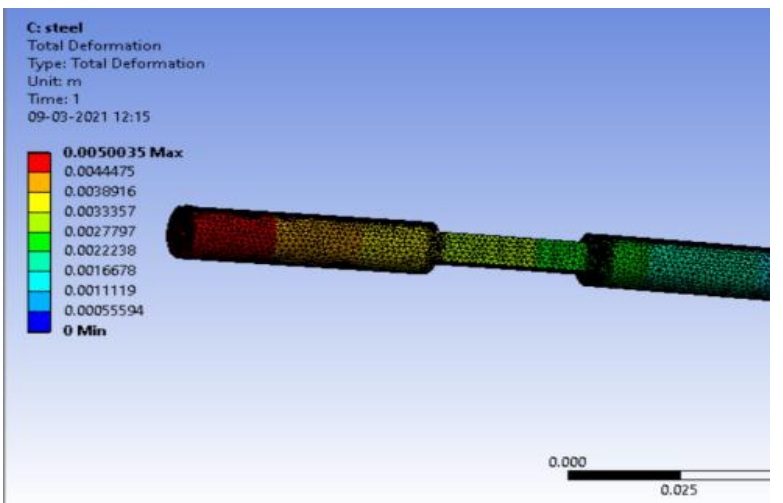

Fig 5 Steel beam subjected to $100 \mathrm{~N}$ lift at free end
Table 1 Simulation results of different loads of lift

\begin{tabular}{|c|c|c|}
\hline Lift (n) & $\begin{array}{c}\text { Aluminium } \\
\text { deflection }(\mathrm{m})\end{array}$ & $\begin{array}{l}\text { Steel deflection } \\
\text { (m) }\end{array}$ \\
\hline 1 & 0.00014 & 0.00005 \\
\hline 10 & 0.0014 & 0.0005 \\
\hline 20 & 0.0028 & 0.001 \\
\hline 30 & 0.0042 & 0.001 \\
\hline 40 & 0.0056 & 0.002 \\
\hline 50 & 0.0070 & 0.0025 \\
\hline 60 & 0.0084 & 0.003 \\
\hline 70 & 0.0098 & 0.0035 \\
\hline 80 & 0.011 & 0.004 \\
\hline 90 & 0.012622 & 0.0045031 \\
\hline 100 & 0.014024 & 0.0050035 \\
\hline 110 & 0.015426 & 0.0055038 \\
\hline 120 & 0.016829 & 0.0060042 \\
\hline 130 & 0.018231 & 0.0065045 \\
\hline 140 & 0.019634 & 0.0070049 \\
\hline 150 & 0.021036 & 0.0075052 \\
\hline 200 & 0.028048 & 0.010007 \\
\hline 250 & 0.03506 & 0.012509 \\
\hline 300 & 0.042072 & 0.01501 \\
\hline
\end{tabular}

\subsection{When subjected to drag}

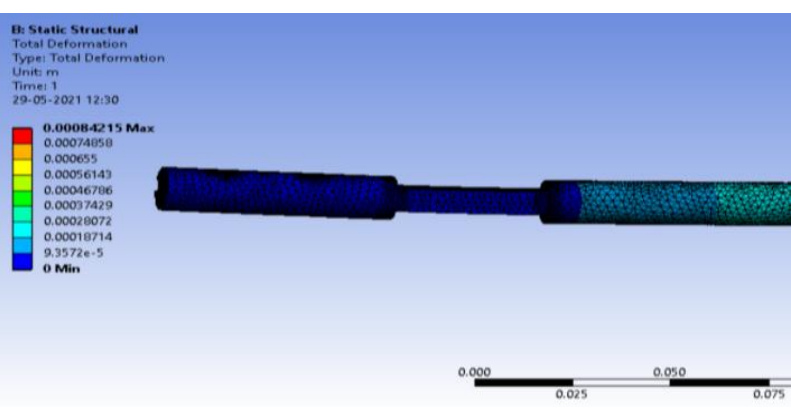

Fig 6 Aluminium beam subjected to $150 \mathrm{~N}$ drag

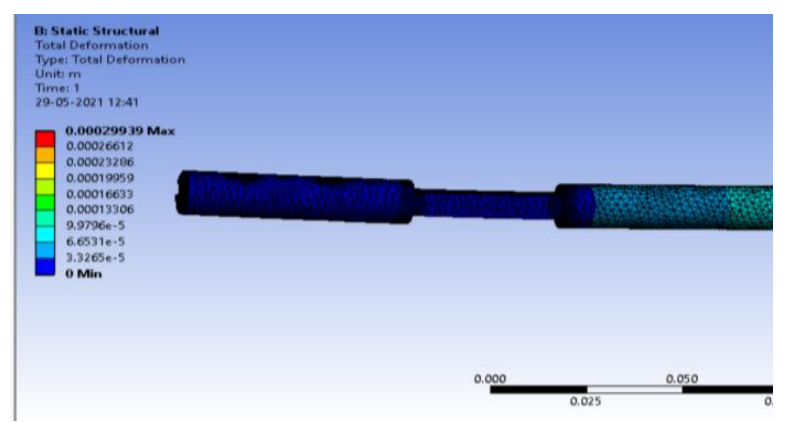

Fig 7 steel beam subjected to $150 \mathrm{~N}$ drag 
Table 2 Simulation results of different loads of drag

\begin{tabular}{|c|c|c|}
\hline $\begin{array}{c}\text { Drag } \\
(\mathrm{N})\end{array}$ & $\begin{array}{c}\text { Aluminium } \\
\text { deflection }(\mathrm{m})\end{array}$ & $\begin{array}{c}\text { Steel } \\
\text { deflection(m) }\end{array}$ \\
\hline 5 & 0.000028 & 0.00000997 \\
\hline 50 & 0.00028 & 0.0000997 \\
\hline 100 & 0.00056 & 0.000199 \\
\hline 150 & 0.00084 & 0.000299 \\
\hline 200 & 0.00112 & 0.000399 \\
\hline 250 & 0.0014 & 0.000498 \\
\hline 300 & 0.00168 & 0.000598 \\
\hline
\end{tabular}

\subsection{Torsional analysis or when subjected to pitching} moment

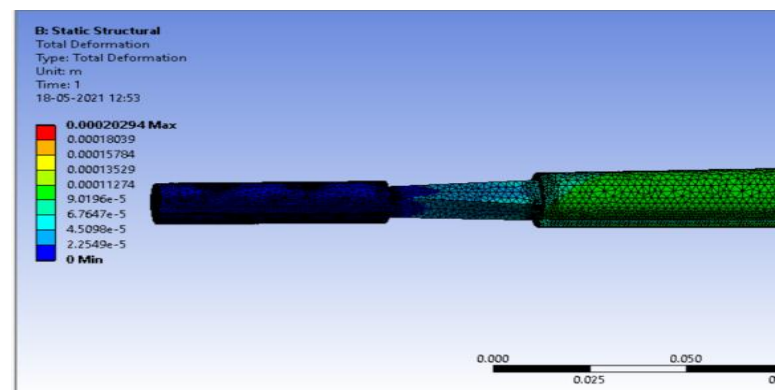

Fig 8 Steel beam subjected to torqe of $10 \mathrm{Nm}$ in anticlockwise direction

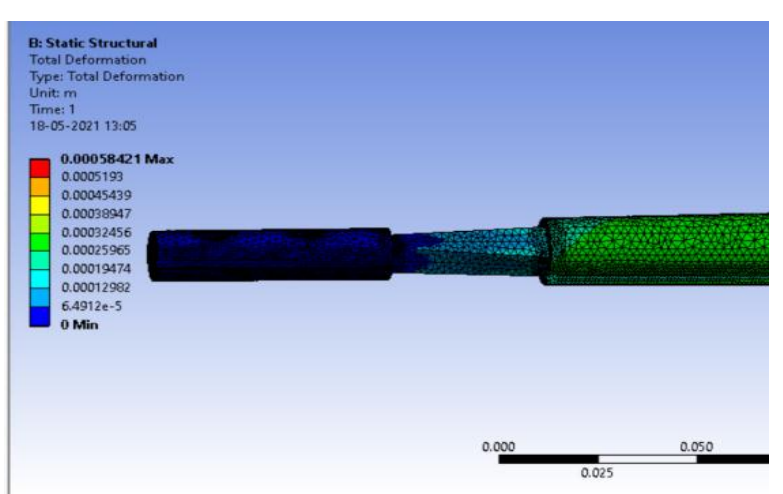

Fig 9 Aluminium beam subjected to torqe of $10 \mathrm{Nm}$ in anticlockwise direction

Table 3 Simulation results of different torque loading conditions

\begin{tabular}{|c|c|c|}
\hline Torque $(\mathrm{Nm})$ & $\begin{array}{c}\text { Aluminium } \\
\text { deflection}(\mathrm{m})\end{array}$ & $\begin{array}{c}\text { Steel } \\
\text { deflection(m) }\end{array}$ \\
\hline 2 & 0.00011 & 0.00004 \\
\hline 4 & 0.000233 & 0.00008 \\
\hline 6 & 0.00035 & 0.00012 \\
\hline 8 & 0.00046 & 0.000162 \\
\hline 10 & 0.00058 & 0.0002 \\
\hline
\end{tabular}

\section{COMBINED LOADING}

\subsection{When the beam is subjected to lift and drag}

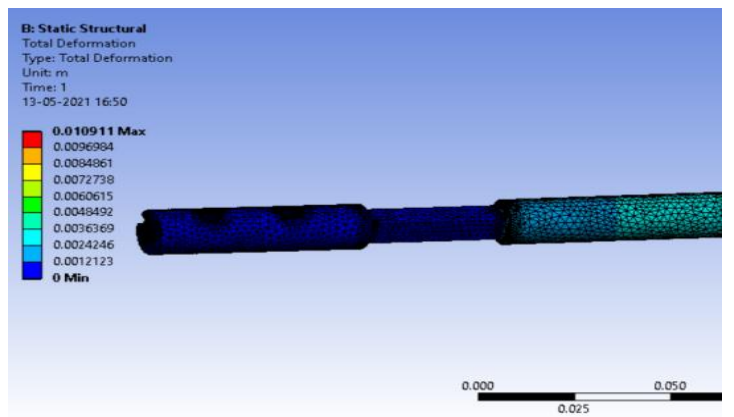

Fig 10 Steel beam with drag of $150 \mathrm{~N}$ and lift of $150 \mathrm{~N}$

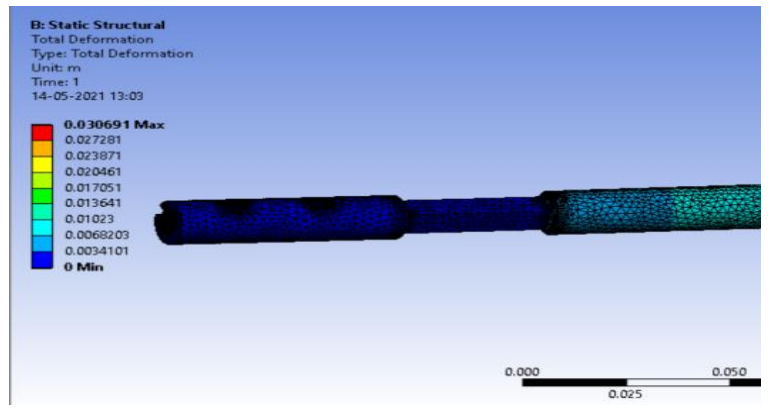

Fig 11 Aluminium beam Loaded under drag of $150 \mathrm{~N}$ and lift of $150 \mathrm{~N}$

Table 4 Simulation results of different lift and drag loading conditions

\begin{tabular}{|c|c|c|c|}
\hline $\begin{array}{c}\text { Loading } \\
\text { in drag } \\
\text { direction } \\
(\mathrm{N})\end{array}$ & $\begin{array}{c}\text { Loading } \\
\text { in lift } \\
\text { direction } \\
(\mathrm{N})\end{array}$ & $\begin{array}{c}\text { Aluminium } \\
\text { deflection } \\
(\mathrm{M})\end{array}$ & $\begin{array}{c}\text { Steel } \\
\text { deflection } \\
(\mathrm{M})\end{array}$ \\
\hline 5 & 5 & 0.001 & 0.00036 \\
\hline 5 & 150 & 0.021 & 0.0077 \\
\hline 5 & 300 & 0.043 & 0.0154 \\
\hline 50 & 5 & 0.072 & 0.0025 \\
\hline 150 & 5 & 0.021 & 0.0076 \\
\hline 150 & 150 & 0.0306 & 0.01 \\
\hline 150 & 300 & 0.0486 & 0.0176 \\
\hline 300 & 5 & 0.0429 & 0.0152 \\
\hline 300 & 150 & 0.048 & 0.0171 \\
\hline 300 & 300 & 0.0613 & 0.0218 \\
\hline
\end{tabular}

bi directional loading (aluminium

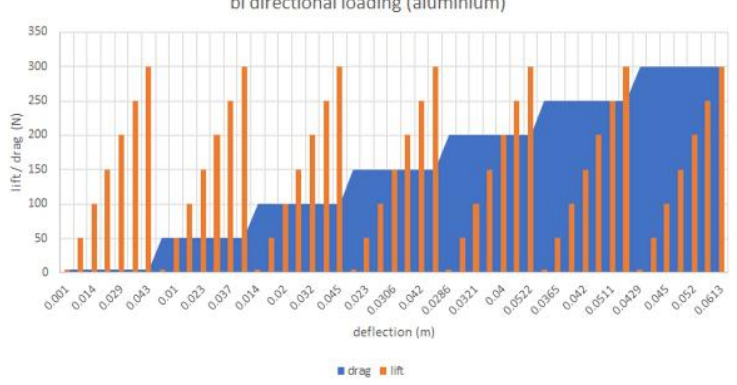

Fig 12 Graphical representation of aluminium beam subjected to lift/ drag of various conditions 


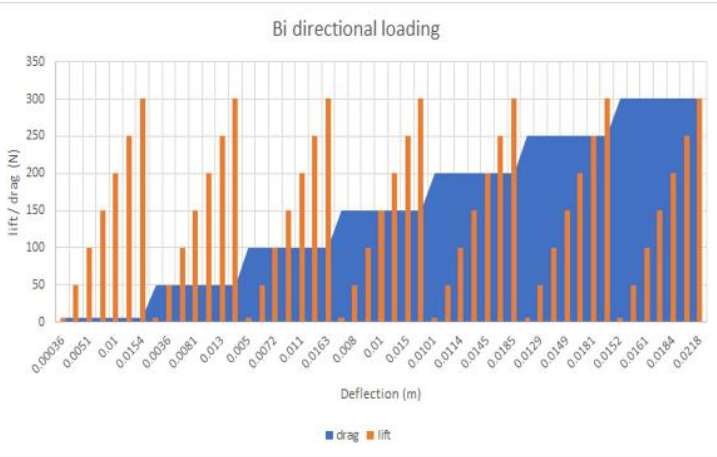

Fig 13 Graphical representation of steel beam subjected to lift/ drag of various conditions

\subsection{Loading under pitching moment and lift}

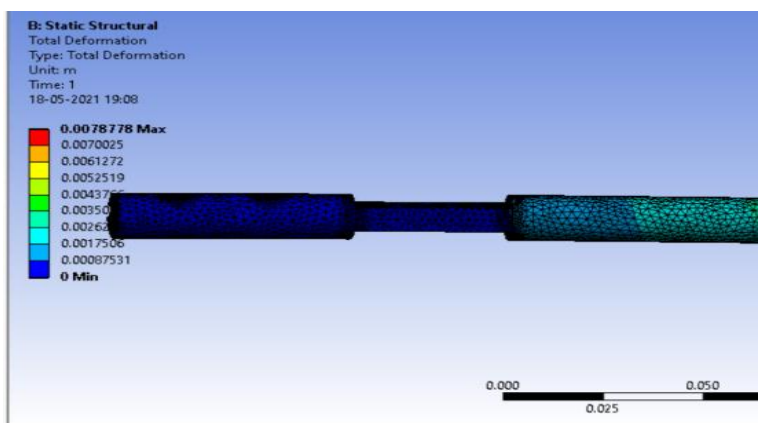

Fig 14 Steel beam subjected to pitching moment 10Nm and lift of $150 \mathrm{~N}$

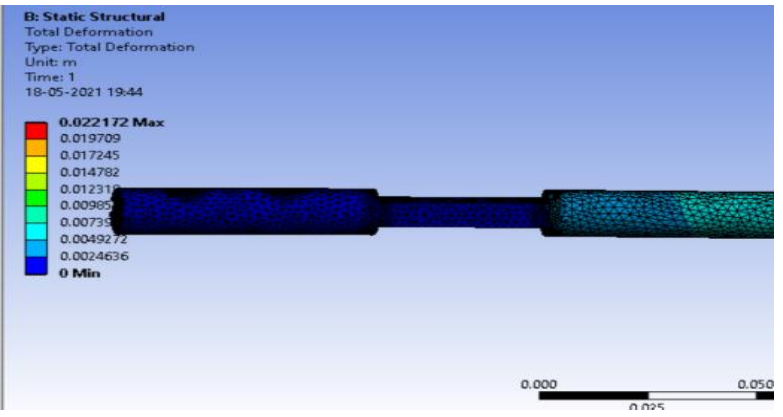

Fig 15 Aluminium beam subjected to pitching moment $10 \mathrm{Nm}$ and lift of $150 \mathrm{~N}$

\subsubsection{Stress analysis}

Stress is a very crucial factor in consideration of failure so the stress analysis is also been made

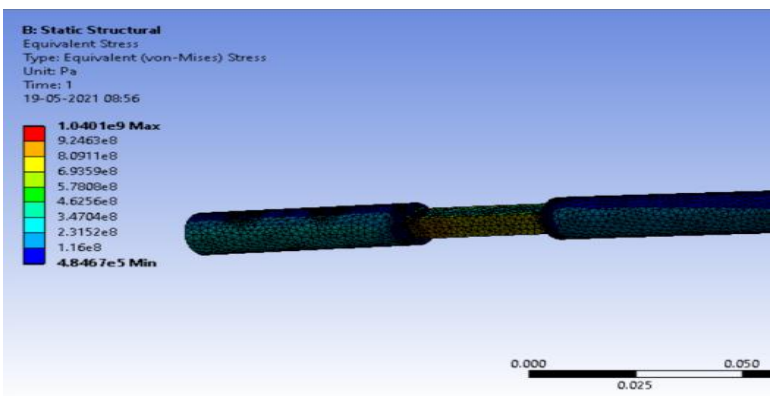

Fig 16 Steel beam subjected to torque of $10 \mathrm{Nm}$ and transverse load of $300 \mathrm{~N}$

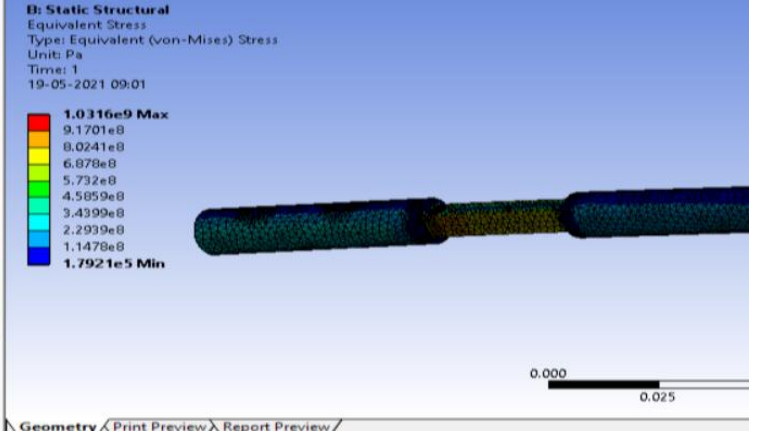

Fig 17 Aluminium beam subjected to torque of $10 \mathrm{Nm}$ and transverse load of $300 \mathrm{~N}$

Table 5 Simulated stress results when different loads of lift and pitching moment is acted

\begin{tabular}{|l|l|l|l|}
\hline $\begin{array}{l}\text { Pitching } \\
\text { moment } \\
(\mathrm{Nm})\end{array}$ & $\begin{array}{l}\text { Lift } \\
(\mathrm{N})\end{array}$ & $\begin{array}{l}\text { Steel beam } \\
\text { stress } \\
\left(\mathrm{N} / \mathrm{m}^{\wedge} 2\right) \\
\left(1^{\wedge} 10^{\wedge} 7\right)\end{array}$ & $\begin{array}{l}\text { Aluminium } \\
\text { beam } \\
\text { stress(N/m} \\
\left(1^{\wedge} 10^{\wedge} 7\right)\end{array}$ \\
\hline 2 & 5 & 3.57 & 3.57 \\
\hline 2 & 150 & 51.7 & 51.6 \\
\hline 2 & 300 & 103 & 103 \\
\hline 6 & 5 & 9.99 & 10 \\
\hline 6 & 150 & 52.1 & 52 \\
\hline 6 & 300 & 103 & 103 \\
\hline 10 & 5 & 1.66 & 1.66 \\
\hline 10 & 150 & 52.5 & 52.4 \\
\hline 10 & 300 & 104 & 1.03 \\
\hline
\end{tabular}

Table 6 Simulated deformation results when subjected to different loads of lift and pitching moment

\begin{tabular}{|l|l|l|l|}
\hline $\begin{array}{l}\text { Pitching } \\
\text { moment } \\
(\mathrm{Nm})\end{array}$ & Lift(N) & $\begin{array}{l}\text { Deflection } \\
\text { steel(m) }\end{array}$ & $\begin{array}{l}\text { Deflection } \\
\text { aluminum } \\
(\mathrm{m})\end{array}$ \\
\hline 2 & 5 & 0.00029 & 0.00083 \\
\hline 2 & 150 & 0.0077 & 0.021 \\
\hline 2 & 300 & 0.0154 & 0.043 \\
\hline 6 & 5 & 0.00037 & 0.001 \\
\hline 6 & 150 & 0.0077 & 0.0219 \\
\hline 6 & 300 & 0.0154 & 0.0435 \\
\hline 10 & 5 & 0.0004 & 0.00128 \\
\hline 10 & 150 & 0.0078 & 0.022 \\
\hline 10 & 300 & 0.0155 & 0.044 \\
\hline
\end{tabular}




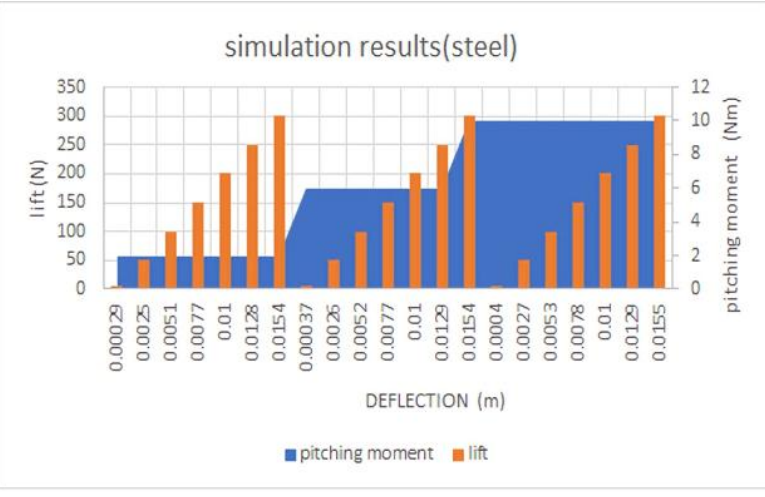

Fig 18 Plot of steel beam subjected to lift and pitching moment against deflection

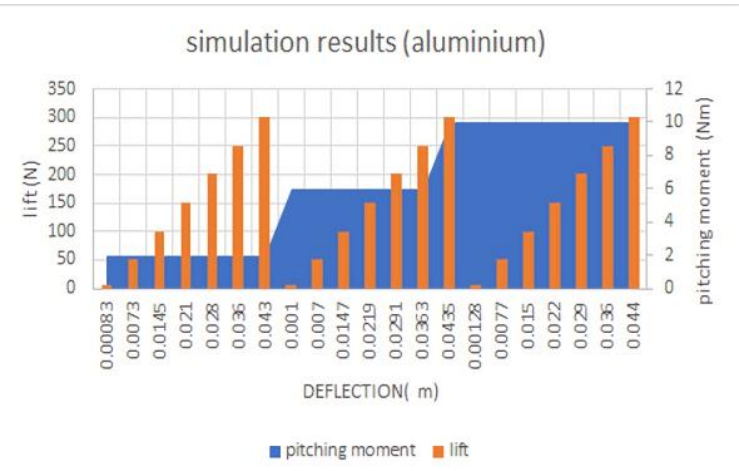

Fig 19 Plot of aluminium beam subjected to lift and pitching moment aginst deflection

\subsection{Beam subjected to pitching moment and drag}

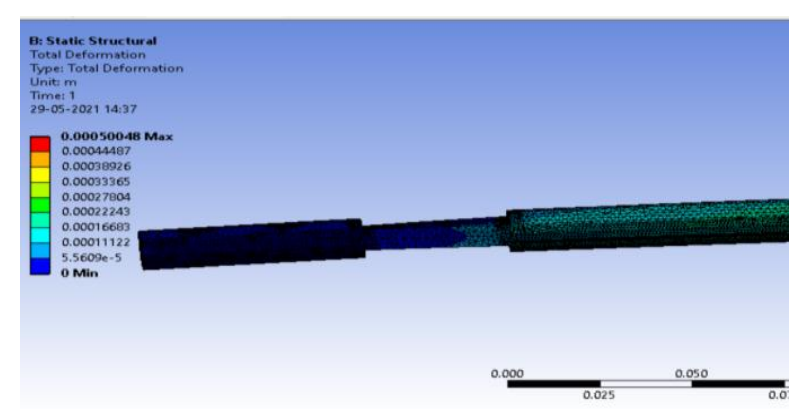

Fig 20 Deflection of Aluminium beam subjected to $150 \mathrm{~N}$ drag and pitching moment of $10 \mathrm{Nm}$

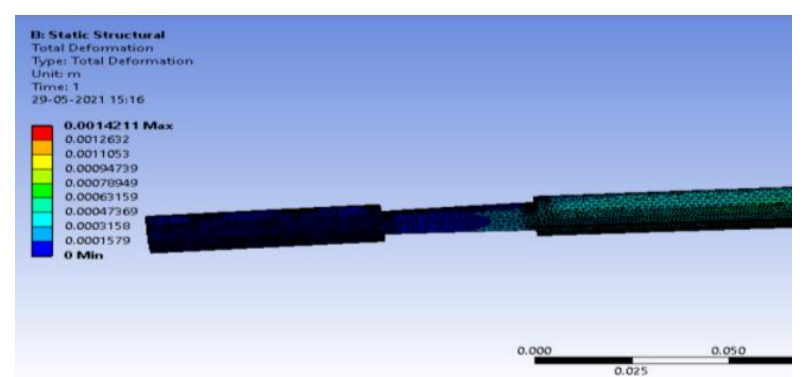

Fig 21 Deflection of steel beam subjected to $150 \mathrm{~N}$ drag and pitching moment of $10 \mathrm{Nm}$

\subsubsection{Stress analysis}

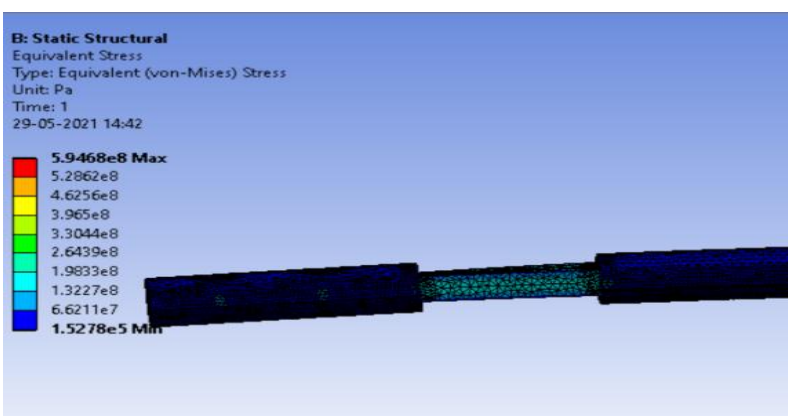

Fig 22 stress of aluminium beam subjected to $300 \mathrm{~N}$ drag and pitching moment of $10 \mathrm{Nm}$

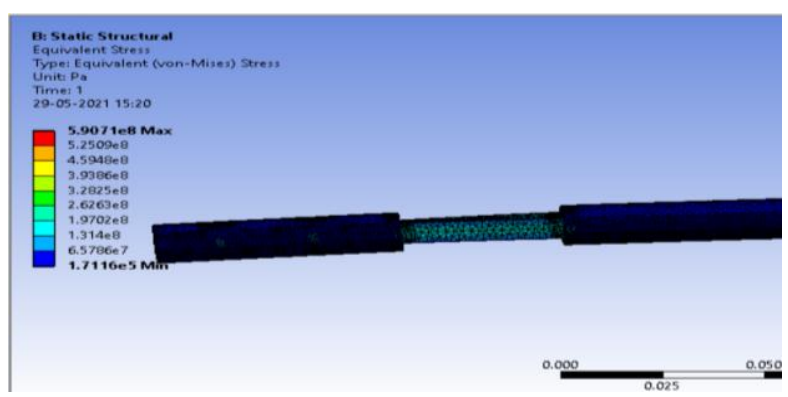

Fig 23 stress of steel beam subjected to $300 \mathrm{~N}$ drag and pitching moment of $10 \mathrm{Nm}$

Table 7 Simulated results of beam when different loads of drag and pitching moment is acted

\begin{tabular}{|c|c|c|c|c|c|}
\hline $\begin{array}{c}\text { Pitchi } \\
\text { ng } \\
\text { mom } \\
\text { ent(N } \\
\mathrm{m})\end{array}$ & $\begin{array}{c}\text { Dra } \\
\mathrm{g}\end{array}$ & $\begin{array}{c}\text { Steel } \\
\text { deflecti } \\
\text { on(m) }\end{array}$ & $\begin{array}{c}\text { Stress } \\
\left(1^{*} 10\right. \\
\wedge 7(\mathrm{~N}\end{array}$ & $\begin{array}{c}\text { Al } \\
\text { deflectio } \\
\mathrm{n}(\mathrm{m})\end{array}$ & $\begin{array}{c}\text { Stress } \\
\left(1^{*} 10^{\wedge} 7\right) \\
\left(\mathrm{N} / \mathrm{m}^{\wedge} 2\right)\end{array}$ \\
\hline 2 & 5 & 0.00005 & 3.3 & 0.00014 & 3.3 \\
\hline 2 & 150 & 0.00033 & 29.6 & 0.00095 & 29.5 \\
\hline 2 & 300 & 0.00063 & 59.3 & 0.00179 & 58.9 \\
\hline 6 & 5 & 0.00013 & 9.99 & 0.00037 & 9.99 \\
\hline 6 & 150 & 0.00041 & 29.7 & 0.00118 & 29.5 \\
\hline 6 & 300 & 0.00071 & 59.4 & 0.002 & 59 \\
\hline 10 & 5 & 0.00021 & 16.6 & 0.00061 & 16.6 \\
\hline 10 & 150 & 0.0005 & 29.8 & 0.00142 & 29.6 \\
\hline 10 & 300 & 0.00079 & 59.4 & 0.0022 & 59 \\
\hline
\end{tabular}




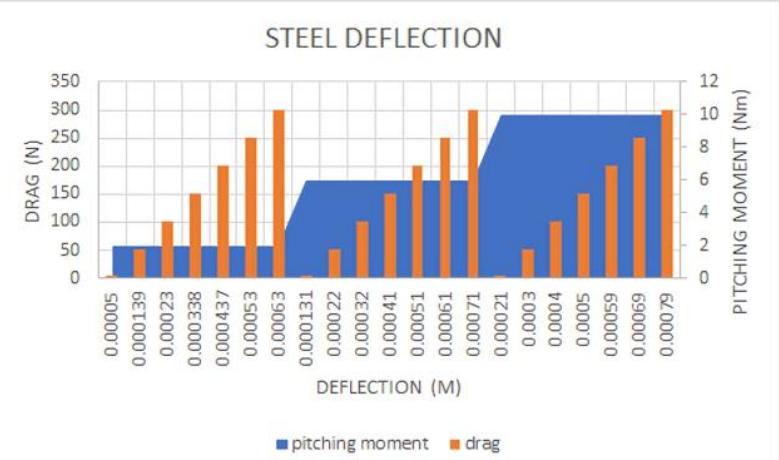

Fig 24 plot of steel beam subjected to drag and pitching moment against deflection

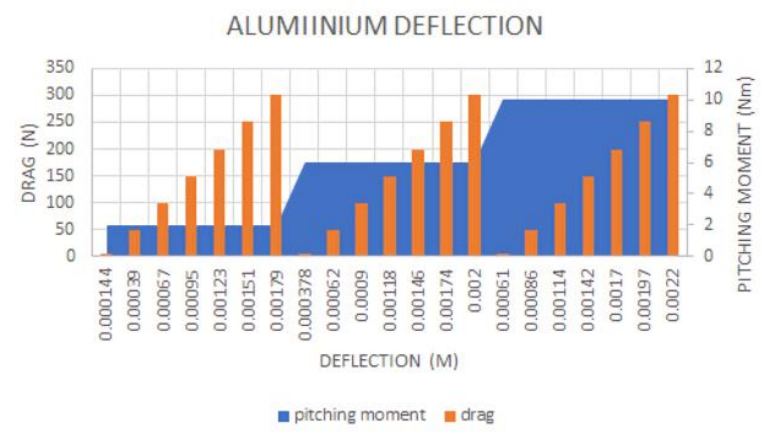

Fig 25 plot of steel beam subjected to drag and pitching moment against deflection

\section{STRESS ANALYSIS}

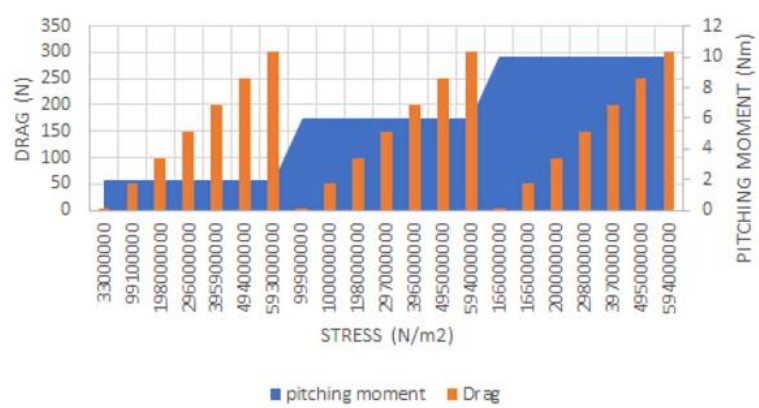

Fig 26 plot of stress analysis of steel beam subjected to drag and pitching moment against deflection

\section{4 when subjected to lift, drag, pitching moment}

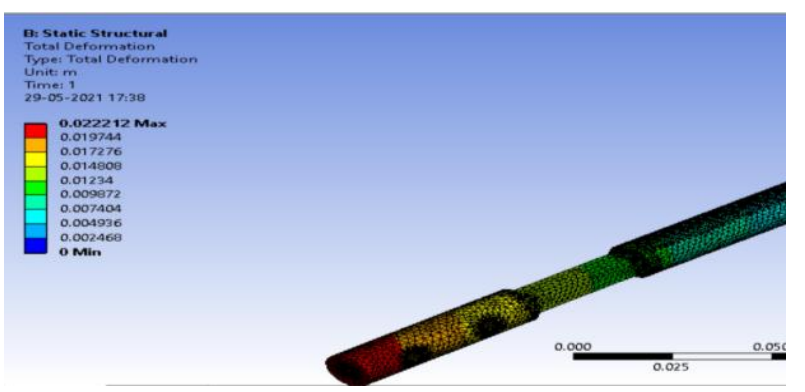

Fig 27 Deflection of aluminium beam subjected to lift $150 \mathrm{~N}$ , drag $150 \mathrm{~N}$ and pitching moment of $10 \mathrm{Nm}$

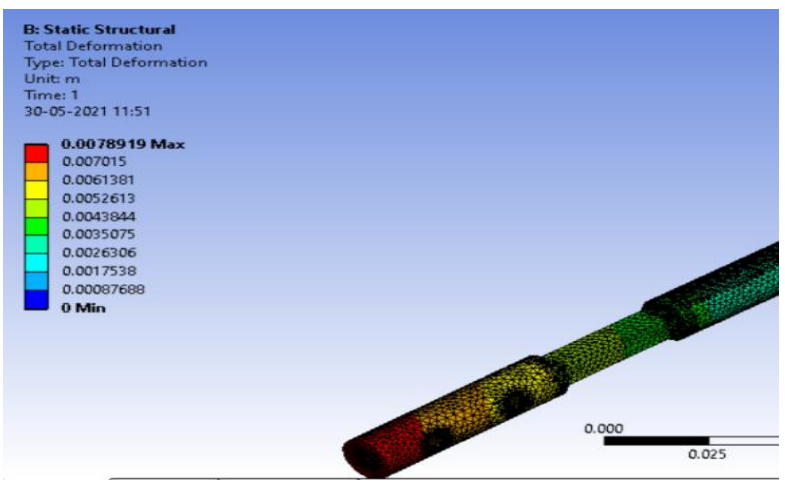

Fig 28 Deflection of steel beam subjected to lift 150N, drag $150 \mathrm{~N}$ and pitching moment of $10 \mathrm{Nm}$

\subsubsection{Stress analysis}

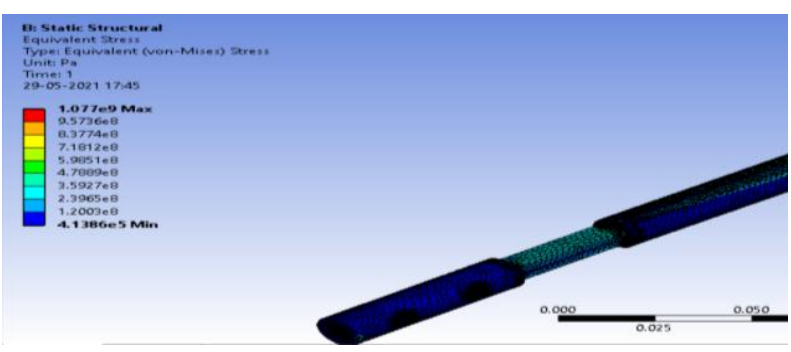

Fig 29 Stress of aluminium beam subjected to lift 300N, drag $300 \mathrm{~N}$ and pitching moment of $10 \mathrm{Nm}$

Table 8 The simulated results of beam when subjected to different loads of lift, drag and pitching moment

\begin{tabular}{|c|c|c|c|c|c|c|}
\hline Drag(N) & Lift(N) & $\begin{array}{c}\text { Moment } \\
(\mathrm{Nm})\end{array}$ & $\begin{array}{c}\text { Aluminium } \\
\text { deflection }(\mathrm{m})\end{array}$ & $\begin{array}{c}\text { Aluminium } \\
\text { stress }\left(\mathrm{N} / \mathrm{m}^{\wedge} 2\right)\left(1 * 10^{\wedge} 7\right)\end{array}$ & $\begin{array}{c}\text { Steel } \\
\text { deflection }(\mathrm{m})\end{array}$ & $\begin{array}{c}\text { Steel } \\
\text { stress }\left(\mathrm{N} / \mathrm{m}^{\wedge} 2\right)\left(1 * 10^{\wedge} 7\right)\end{array}$ \\
\hline 5 & 5 & 2 & 0.0008 & 3.57 & 0.000295 & 3.57 \\
\hline 5 & 150 & 2 & 0.021 & 51.7 & 0.00772 & 51.8 \\
\hline 5 & 300 & 2 & 0.043 & 103 & 0.0154 & 103 \\
\hline 150 & 5 & 2 & 0.0013 & 29.5 & 0.000437 & 29.7 \\
\hline 150 & 150 & 2 & 0.021 & 53.6 & 0.00773 & 53.6 \\
\hline 150 & 300 & 2 & 0.043 & 105 & 0.0154 & 105 \\
\hline
\end{tabular}


International Journal of Applied Engineering Research ISSN 0973-4562 Volume 16, Number 7 (2021) pp. $525-537$

(C) Research India Publications. https://dx.doi.org/10.37622/IJAER/16.7.2021.525-537

\begin{tabular}{|c|c|c|c|c|c|c|}
\hline $\operatorname{Drag}(\mathrm{N})$ & $\operatorname{Lift}(\mathrm{N})$ & $\begin{array}{l}\text { Moment } \\
(\mathrm{Nm})\end{array}$ & $\begin{array}{l}\text { Aluminium } \\
\text { deflection(m) }\end{array}$ & $\begin{array}{c}\text { Aluminium } \\
\operatorname{stress}\left(\mathrm{N} / \mathrm{m}^{\wedge} 2\right)\left(1 * 10^{\wedge} 7\right)\end{array}$ & $\begin{array}{c}\text { Steel } \\
\text { deflection }(m)\end{array}$ & $\begin{array}{c}\text { Steel } \\
\text { stress }\left(\mathrm{N} / \mathrm{m}^{\wedge} 2\right)\left(1 * 10^{\wedge} 7\right)\end{array}$ \\
\hline 300 & 5 & 2 & 0.0019 & 59 & 0.00069 & 59.4 \\
\hline 300 & 150 & 2 & 0.021 & 66.5 & 0.0077 & 66.9 \\
\hline 300 & 300 & 2 & 0.043 & 107 & 0.0154 & 107 \\
\hline 5 & 5 & 6 & 0.001 & 9.99 & 0.00037 & 9.99 \\
\hline 5 & 150 & 6 & 0.021 & 52.1 & 0.00779 & 52.2 \\
\hline 5 & 300 & 6 & 0.043 & 104 & 0.0154 & 104 \\
\hline 150 & 5 & 6 & 0.0014 & 29.6 & 0.00051 & 29.8 \\
\hline 150 & 150 & 6 & 0.021 & 54 & 0.0078 & 54 \\
\hline 150 & 300 & 6 & 0.043 & 105 & 0.01549 & 106 \\
\hline 300 & 5 & 6 & 0.002 & 59.1 & 0.00077 & 59.4 \\
\hline 300 & 150 & 6 & 0.02 & 66.2 & 0.00783 & 66.6 \\
\hline 300 & 300 & 6 & 0.043 & 107 & 0.0155 & 107 \\
\hline 5 & 5 & 10 & 0.001 & 16.6 & 0.00045 & 16.6 \\
\hline 5 & 150 & 10 & 0.022 & 52.6 & 0.00787 & 52.6 \\
\hline 5 & 300 & 10 & 0.043 & 104 & 0.0155 & 104 \\
\hline 150 & 5 & 10 & 0.0016 & 29.6 & 0.00059 & 29.8 \\
\hline 150 & 150 & 10 & 0.022 & 54.4 & 0.00789 & 54.4 \\
\hline 150 & 300 & 10 & 0.043 & 106 & 0.0155 & 106 \\
\hline 300 & 5 & 10 & 0.002 & 59.1 & 0.00085 & 59.5 \\
\hline 300 & 150 & 10 & 0.023 & 66 & 0.0079 & 66.4 \\
\hline 300 & 300 & 10 & 0.0438 & 108 & 0.0155 & 108 \\
\hline
\end{tabular}

pitching moment against deflection

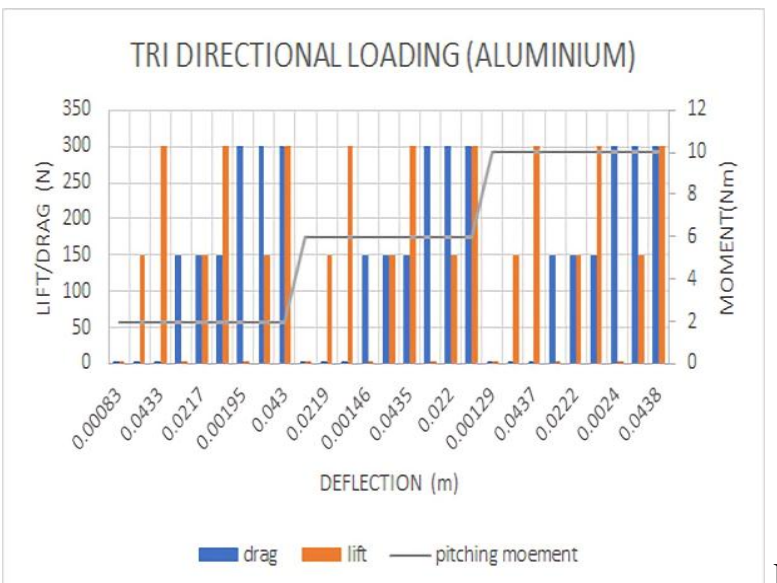

31 plot of aluminium beam subjected to lift, drag and 


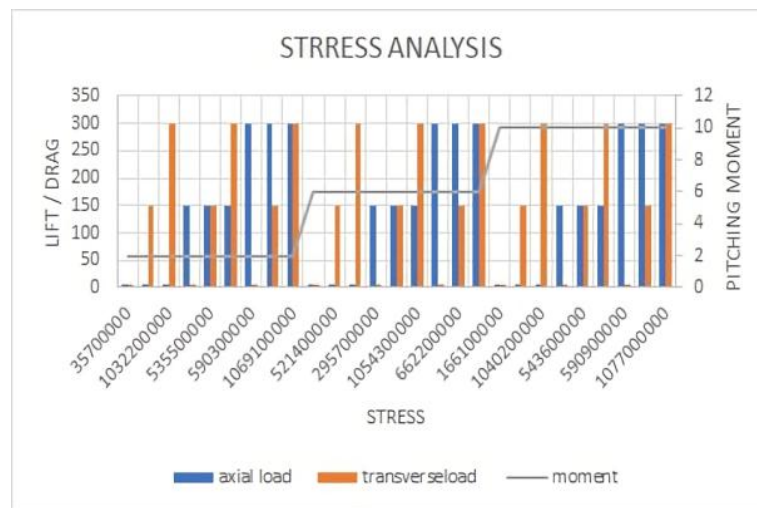

Fig 33 plot of stress analysis of beam when subjected to lift, drag and pitching moment

\section{THEORITICAL RESULTS}

\section{UNI DIRECTONAL LOADING}

\subsection{When subjected to only lift}

$\mathrm{D}=15 \mathrm{~mm}=1.5 * 10^{-2} \mathrm{~m}$.

$\mathrm{L}=30 * 10^{-2} \mathrm{~m}$

$\mathrm{E}=71.7 * 10^{9} \mathrm{~Pa}$

First consider circular section of whole beam as one

To find moment of Inertia of circular section

$I_{c}=\frac{\pi r^{4}}{4}=\frac{\pi\left(0.75 * 10^{-2}\right)^{4}}{4}$

$\mathrm{I}_{\mathrm{c}}=0.2485 * 10^{-8} \mathrm{~m}^{4}$

Next consider the square section which is $0.8 \mathrm{~cm} * 0.8 \mathrm{~cm}$

To find moment of Inertia for square section

$I_{s q}=\frac{b d^{3}}{12}+\frac{d^{3}}{12}$

$$
=\frac{0.8^{4}}{12}+\frac{0.8^{4}}{12}=0.0682 * 10^{-8} \mathrm{~m}^{4}
$$

There are two square sections in the beam with same dimensions.

$\mathrm{I}_{\mathrm{sq}}=2 * 0.0682 * 10^{-8}=0.1365 * 10^{-8} \mathrm{~m}^{4}$

Next considering two screws and calculate its moment of inertia

$I_{S C}=\frac{0.3 * 0.4^{3}}{12}+\frac{0.4 * 0.3^{3}}{12}=0.0025 * 10^{-8} \mathrm{~m}^{4}$

$I_{s c}=2 * 0.0025 * 10^{-8}=0.005 * 10^{-8} \mathrm{~m}^{4}$

$\mathrm{I}=\mathrm{I}_{\mathrm{c}}-\mathrm{I}_{\mathrm{sq}}-\mathrm{I}_{\mathrm{sc}}$

$I=\left(0.2485^{*} 10^{-8}\right)-\left(0.0682 * 10^{-8}\right)-\left(0.0682 * 10^{-8}\right)$

$\mathrm{I}=0.10697 * 10^{-8} \mathrm{~m}^{4}$

For, $\mathrm{w}=10 \mathrm{~kg}$ or $100 \mathrm{~N}$ $\delta=\frac{w^{3}}{3 E I}$

$\delta=11.73 \mathrm{~mm}$

Similarily the theatrical calculations are made for each loads starting from $100 \mathrm{gms}$ to $30 \mathrm{~kg}$ with an interval of $100 \mathrm{gms}$ for aluminium and steel and are tabulated

Table 9 Calculated results when subjected to different loads of lift

\begin{tabular}{|c|c|c|}
\hline Lift (n) & $\begin{array}{c}\text { Alluminium } \\
\text { deflection }(\mathrm{m})\end{array}$ & $\begin{array}{c}\text { Steel } \\
\text { deflection }(\mathrm{m})\end{array}$ \\
\hline 1 & 0.00012 & 0.00004 \\
\hline 10 & 0.0012 & 0.00041 \\
\hline 20 & 0.0024 & 0.00082 \\
\hline 30 & 0.0036 & 0.0012 \\
\hline 40 & 0.0048 & 0.0016 \\
\hline 50 & 0.0060 & 0.0020 \\
\hline 60 & 0.0072 & 0.0024 \\
\hline 70 & 0.0084 & 0.0028 \\
\hline 80 & 0.0096 & 0.0032 \\
\hline 90 & 0.010 & 0.0037 \\
\hline 100 & 0.012 & 0.0041 \\
\hline 110 & 0.013 & 0.0045 \\
\hline 120 & 0.014 & 0.0049 \\
\hline 130 & 0.015 & 0.0053 \\
\hline 140 & 0.016 & 0.0057 \\
\hline 150 & 0.018 & 0.0061 \\
\hline 200 & 0.024 & 0.0082 \\
\hline 250 & 0.03 & 0.010 \\
\hline 300 & 0.036 & 0.012 \\
\hline
\end{tabular}

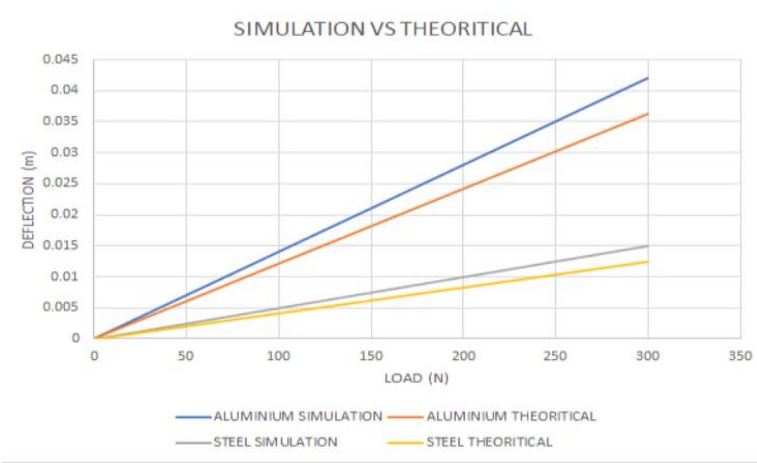

Fig 34 Plot of simulation and theoritical results of aluminium and steel when subjected to lift 


\subsection{WHEN SUBJECTED TO DRAG}

Deflection of a cantilever beam subjected to axial load of $\mathrm{p}$ is (PL/AE)

WHERE,

$$
\begin{aligned}
& \mathrm{P}=\text { axial load } \\
& \mathrm{L}=\text { length of the beam } \\
& \mathrm{A}=\text { area of cross section } \\
& \mathrm{E}=\text { young's modulus }
\end{aligned}
$$

So beam is divided into 5 sections in which there are 2 equivalent circular cross sections and 2 cubioial cross sections with same dimensions and a 1circular cross section.

So total deformation $=\left(P L_{1}\right) /\left(A_{1} E\right)+\left(P L_{2}\right) /\left(A_{1} E\right)+$ $\left(P L_{3}\right) /\left(A_{1} E\right)$

As the load is same through out the beam and the beam is homogeneous

By substituting the beam dimensions in the above formula, we get the formula in terms of $\mathrm{p}$ as total deflection = $0.000008 \mathrm{P}$ for aluminium and for steel the formula is $0.0000028 \mathrm{P}$

By substituting the respective drag we get the tabulation to be

Table 10

\begin{tabular}{|c|c|c|}
\hline Drag(N) & $\begin{array}{c}\text { Steel beam } \\
\text { deflection(m) }\end{array}$ & $\begin{array}{c}\text { Aluminium beam } \\
\text { deflection(m) }\end{array}$ \\
\hline 5 & 0.000014 & 0.00004 \\
\hline 50 & 0.00014 & 0.0004 \\
\hline 100 & 0.00028 & 0.0008 \\
\hline 150 & 0.00042 & 0.0012 \\
\hline 200 & 0.00056 & 0.0016 \\
\hline 250 & 0.0007 & 0.002 \\
\hline 300 & 0.00084 & 0.0024 \\
\hline
\end{tabular}

\section{DEFLECTION OF ALUMINIUM AND STEEL}

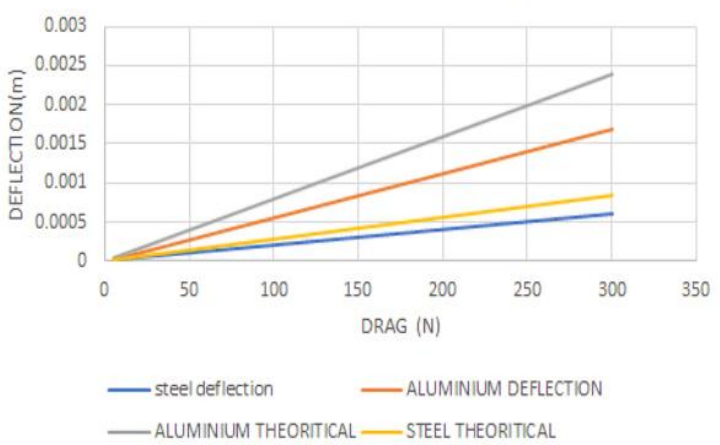

Fig 35 Plot of simulation and theoritical results of aluminium and steel when subjected to drag

\subsection{WHEN PITCHING MOMENT IS ACTED}

In this case we should mainly matter about the angle of twist and the deflection due to torque is so minimal so that we can neglect the deformation due to torque.

Angle of twist $=(\mathrm{TL}) /(\mathrm{GJ})$

WHERE ; $\mathrm{T}=$ torsion

$$
\begin{aligned}
\mathrm{L} & =\text { length of beam } \\
\mathrm{G} & =\text { rigidity modulus }
\end{aligned}
$$

(for aluminium $=26.9 \mathrm{GPA}$ and for steel 77.2Gpa)

$\mathbf{J}=$ Polar moment of inertia $\left(3.14 *\left(d^{\wedge} 4\right)\right) / 32$

On substuiting the above values

\begin{tabular}{|c|c|c|}
\hline $\begin{array}{c}\text { TORSION } \\
(\mathrm{Nm})\end{array}$ & $\begin{array}{c}\text { ANGLE OF } \\
\text { TWIST(aluminium) } \\
(\mathrm{rad})\end{array}$ & $\begin{array}{c}\text { ANGLE OF } \\
\text { TWIST } \\
(\text { STEEL) } \\
(\mathrm{rad})\end{array}$ \\
\hline 2 & 0.257 & 0.179 \\
\hline 4 & 0.514 & 0.358 \\
\hline 6 & 0.772 & 0.538 \\
\hline 8 & 1.02 & 0.717 \\
\hline 10 & 1.28 & 0.896 \\
\hline
\end{tabular}

\section{7 . COMBINED LOADING}

\subsection{LOADING UNDER LIFT AND DRAG}

Now for theatrical case consider a cantilever beam subjected to drag of $5 \mathrm{~N}$ and lift of $5 \mathrm{~N}$

For deflection of a cantilever beam subjected to both axial and longitudinal load

$$
\begin{aligned}
\delta & =(\mathrm{W} / \mathrm{P})(\mathrm{L} *(\tan \mathrm{U} / \mathrm{U})-\mathrm{L}) \\
\mathrm{U} & =\mathrm{L}(\operatorname{sqrt}(\mathrm{p} / \mathrm{EI})
\end{aligned}
$$

Where $\mathrm{p}=$ axial load

$$
\begin{aligned}
& \mathrm{W}=\text { longitudinal load } \\
& \mathrm{L}=\text { length of beam }
\end{aligned}
$$

By the above mentioned formula we calculated the deflection of beam with varying longitudinal load and axial load for aluminium and steel 
Table 12

\begin{tabular}{|c|c|c|c|}
\hline $\begin{array}{c}\text { DRAG } \\
(\mathrm{N})\end{array}$ & $\begin{array}{c}\text { LIFT } \\
(\mathrm{N})\end{array}$ & $\begin{array}{c}\text { DEFLECTION } \\
\text { ALLUMINIUM } \\
(\mathrm{m})\end{array}$ & $\begin{array}{c}\text { DEFLECTION } \\
\text { STEEL }(\mathrm{m})\end{array}$ \\
\hline 5 & 5 & 0.0006 & 0.0002 \\
\hline 5 & 150 & 0.018 & 0.0061 \\
\hline 5 & 300 & 0.036 & 0.012 \\
\hline 150 & 5 & 0.00065 & 0.0002 \\
\hline 150 & 150 & 0.019 & 0.0063 \\
\hline 150 & 300 & 0.039 & 0.012 \\
\hline 300 & 5 & 0.0007 & 0.0002 \\
\hline 300 & 150 & 0.021 & 0.0065 \\
\hline 300 & 300 & 0.042 & 0.013 \\
\hline
\end{tabular}

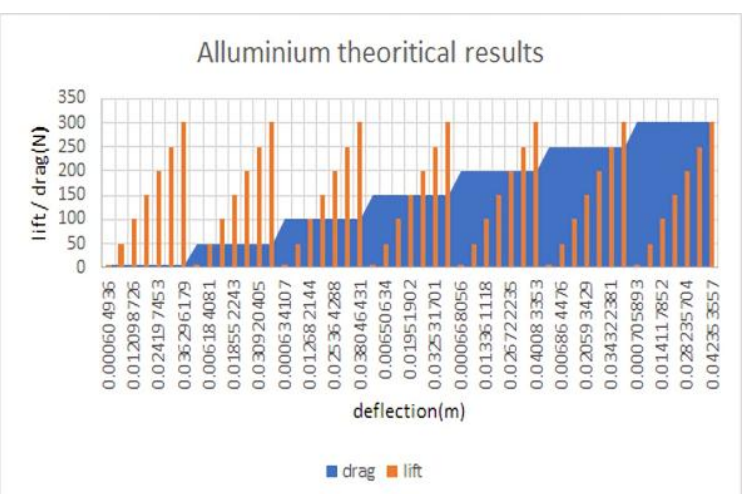

Fig 36 Plot of aluminium beam subjected to lift\& drag against deflection

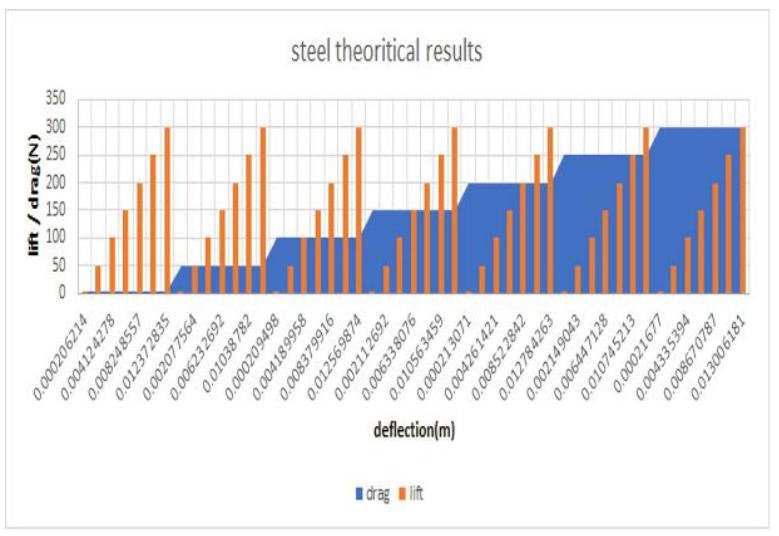

Fig 37 Plot of steel beam subjected to lift \& drag aginst deflection

\subsection{WHEN PITCHING MOMENT AND LIFT IS ACTED}

Here torsion produces angle of twist and the transverse force produces deflection. The deflection due to pitching moment is so small that can be negligible.
By using the given formulas for lift and angle of twist the values are being tabulated.

Table 13 Theoritial results of beam subjected to different loads of lift and pitching moment

\begin{tabular}{|c|c|c|c|}
\hline $\begin{array}{c}\text { Pitching } \\
\text { moment } \\
(\mathrm{Nm})\end{array}$ & $\begin{array}{c}\text { Lift } \\
(\mathrm{N})\end{array}$ & $\begin{array}{c}\text { Deflection } \\
\text { steel }(\mathrm{m})\end{array}$ & $\begin{array}{c}\text { Deflection } \\
\text { aluminium } \\
(\mathrm{m})\end{array}$ \\
\hline 2 & 50 & 0.0020 & 0.0060 \\
\hline 2 & 150 & 0.0061 & 0.018 \\
\hline 2 & 300 & 0.012 & 0.036 \\
\hline 6 & 5 & 0.00020 & 0.00060 \\
\hline 6 & 150 & 0.0061 & 0.018 \\
\hline 10 & 300 & 0.012 & 0.036 \\
\hline 10 & 5 & 0.00020 & 0.00060 \\
\hline 10 & 150 & 0.0061 & 0.018 \\
\hline 10 & 300 & 0.012 & 0.036 \\
\hline
\end{tabular}

Pitching moment produces angle of twist and can be inferred from table 11

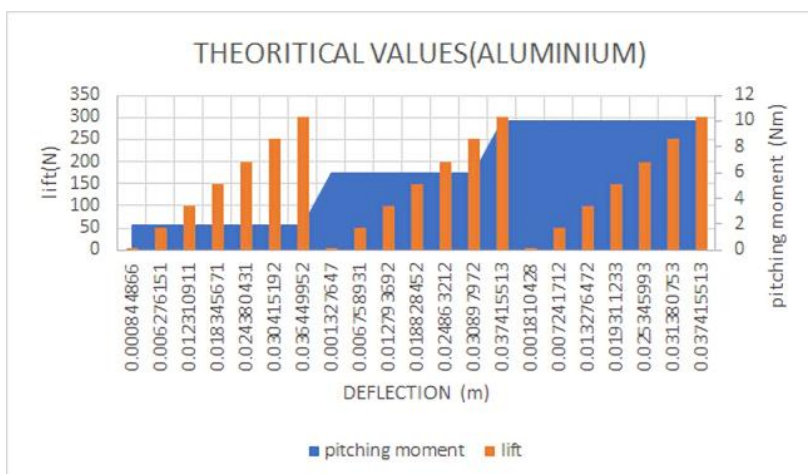

Fig38 Plot of aluminium beam when subjected to lift and pitching moment against deflection

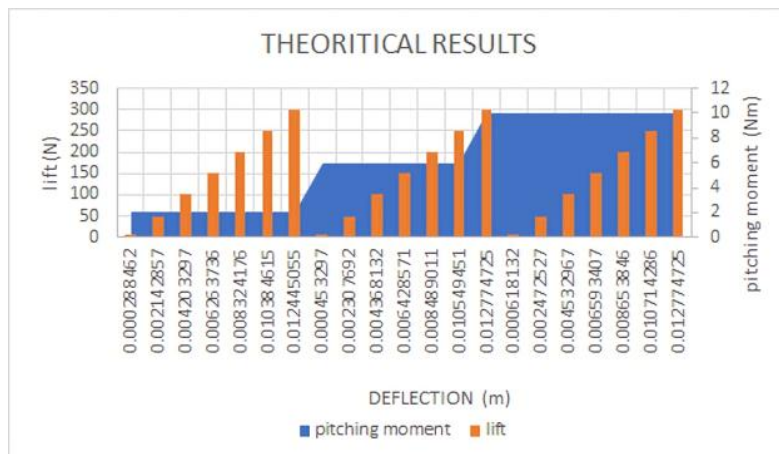

Fig 39 Plot of steel beam when subjected to lift and pitching moment against deflection 


\subsection{WHEN LOADED UNDER PITCHING MOMENT AND DRAG}

As discussed above, pitching moment produces the angle of twist and a minimal deflection which can be neglected, we can consider the deflection only due to drag. But in this we consider the deflection due to drag and pitcjing moment. By using the formulas discussed before, theoritical values are calculated and tabulated. (table 14)

Table 14 Calculated results of beam when subjected to different loads of drag and pitching moment

\begin{tabular}{|c|c|c|c|}
\hline $\begin{array}{c}\text { Moment } \\
(\mathrm{Nm})\end{array}$ & Drag(N) & $\begin{array}{c}\text { Deflection } \\
\text { of steel } \\
\text { beam(m) }\end{array}$ & $\begin{array}{c}\text { Deflection of } \\
\text { aluminium } \\
\text { beam }(\mathrm{m})\end{array}$ \\
\hline 2 & 5 & 0.00009 & 0.00028 \\
\hline 2 & 150 & 0.0005 & 0.0014 \\
\hline 2 & 300 & 0.0009 & 0.0026 \\
\hline 6 & 150 & 0.00066 & 0.0019 \\
\hline 6 & 300 & 0.0012 & 0.0036 \\
\hline 10 & 5 & 0.00042 & 0.0012 \\
\hline 10 & 150 & 0.0008 & 0.0024 \\
\hline 10 & 300 & 0.0012 & 0.0036 \\
\hline
\end{tabular}

angle of twist that is produced by the pitching moment can be inferred from table 11

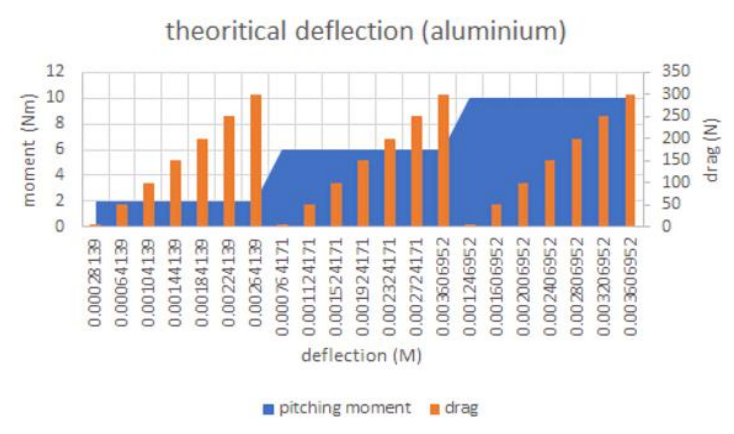

Fig 40 Plot of aluminium beam subjected to pitching moment and drag aginst deflection theoritical deflection (steel)

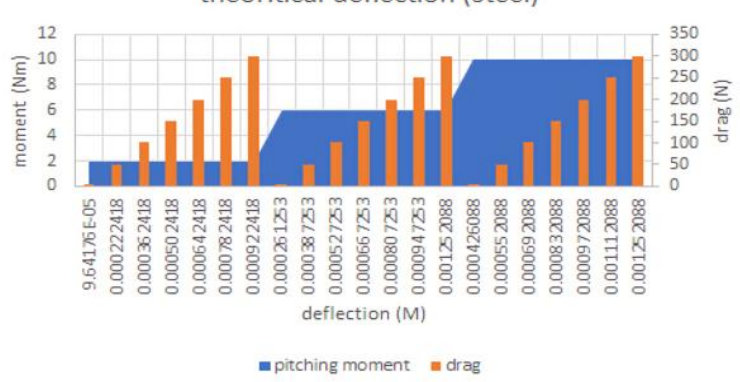

Fig 41 Plot of aluminium beam subjected to pitching moment and drag aginst deflection

\subsection{When lift, drag and pitching moment is acted}

As discussed above, pitching moment produces the angle of twist and a minimal deflection which can be neglected, we can consider the deflection only due to lift and drag. But in this we consider the deflection due to lift ,drag and pitching moment. By using the formulas discussed before, theoritical values are calculated and tabulated.

Table 15

\begin{tabular}{|c|c|c|c|c|}
\hline $\begin{array}{l}\text { Drag } \\
(\mathrm{N})\end{array}$ & $\begin{array}{l}\text { Lift } \\
(\mathrm{N})\end{array}$ & $\begin{array}{c}\text { Moment } \\
(\mathrm{Nm})\end{array}$ & $\begin{array}{c}\text { Deflection of } \\
\text { aluminium } \\
\text { beam }(\mathrm{m})\end{array}$ & $\begin{array}{c}\text { Deflection of } \\
\text { steel } \\
\text { beam }(\mathrm{m})\end{array}$ \\
\hline 5 & 5 & 2 & 0.00084 & 0.00028 \\
\hline 5 & 150 & 2 & 0.018 & 0.0062 \\
\hline 5 & 300 & 2 & 0.036 & 0.012 \\
\hline 150 & 5 & 2 & 0.00082 & 0.00029 \\
\hline 150 & 150 & 2 & 0.019 & 0.0064 \\
\hline 150 & 300 & 2 & 0.039 & 0.012 \\
\hline 300 & 5 & 2 & 0.00094 & 0.00029 \\
\hline 300 & 150 & 2 & 0.021 & 0.0065 \\
\hline 300 & 300 & 2 & 0.042 & 0.013 \\
\hline 5 & 5 & 6 & 0.0013 & 0.00045 \\
\hline 5 & 150 & 6 & 0.018 & 0.0064 \\
\hline 5 & 300 & 6 & 0.037 & 0.012 \\
\hline 150 & 5 & 6 & 0.0013 & 0.00045 \\
\hline 150 & 150 & 6 & 0.020 & 0.0065 \\
\hline 150 & 300 & 6 & 0.039 & 0.012 \\
\hline 300 & 5 & 6 & 0.0014 & 0.00046 \\
\hline 300 & 150 & 6 & 0.021 & 0.0067 \\
\hline 300 & 300 & 6 & 0.043 & 0.013 \\
\hline 5 & 5 & 10 & 0.0018 & 0.00061 \\
\hline 5 & 150 & 10 & 0.019 & 0.0065 \\
\hline 5 & 300 & 10 & 0.037 & 0.012 \\
\hline 150 & 5 & 10 & 0.0018 & 0.00062 \\
\hline 150 & 150 & 10 & 0.020 & 0.0067 \\
\hline 150 & 300 & 10 & 0.040 & 0.013 \\
\hline 300 & 5 & 10 & 0.0019 & 0.00062 \\
\hline 300 & 150 & 10 & 0.022 & 0.0069 \\
\hline 300 & 300 & 10 & 0.043 & 0.013 \\
\hline
\end{tabular}

The angle of twist produced by the pitching moment is inferred from table 11 


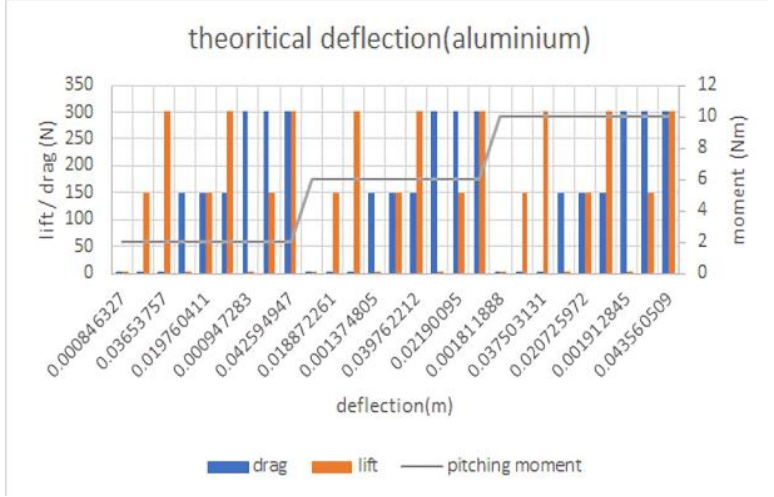

Fig 42 Plot of aluminium beam subjected to lift, drag and pitching moment against deflection

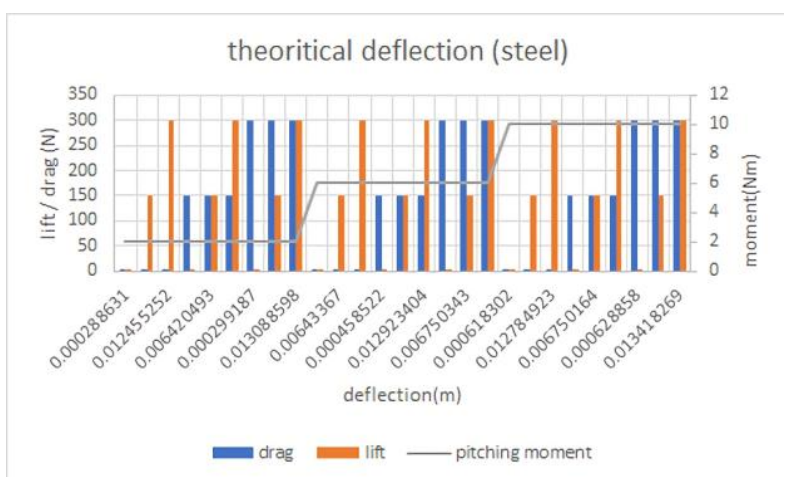

Fig 43 Plot of aluminium beam subjected to lift, drag and pitching moment against deflection

\section{MESH INDEPENDENCE TEST}

We had conducted a mesh independence test to know whether the simulation depends on type of mesh we use. For better accuracy we mesh should be independent

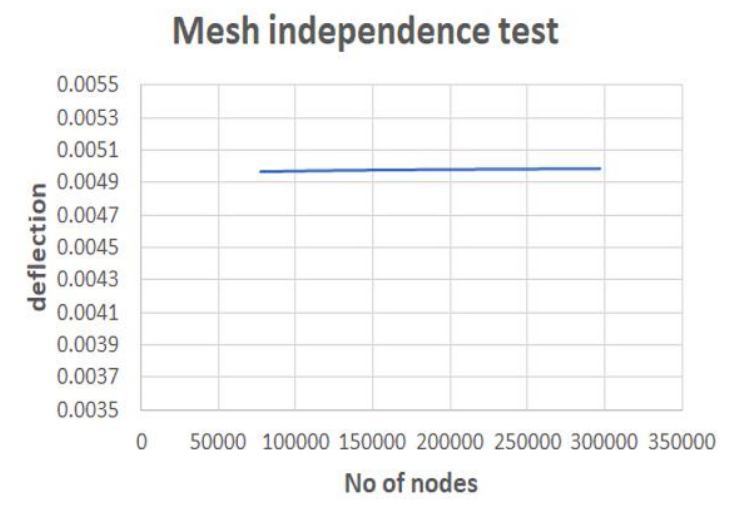

Fig 44 mesh independence test

\section{Conclusion}

We had concluded that the steel beam is more efficient than the aluminium beam. As per our simulation results the beam with the mentioned dimensions well suit for the design of 3 component strain gauge balance. The further work is conserned with the fabrication of balance that is capable of sensing miniumum of $100 \mathrm{gms}$ weight.

\section{References}

[1] Design and development of a three component strain gauge wind tunnel balance by Frederik Francois Pieterse

[2] J.W.Hou , S.L.Twu : optimum design of internal strain gauge balance : June 2017 :Vol 109/257

[3] Milan tomin, marco scipioni, Benjamin gattiDesign, construction testing and of three component force balance for educational wind tunnel in undergraduate aerodynamics - 2020 29

[4] Strain gauge Balance Lloyd R. Jenkinson, James F. MarchmanIII, in Aircraft Design Projects, 2003

[5] Thierry Alonso, Gregory Chagnon- Strain gauge based 3D shape monitoring of beam structures using finite width gauge model - HAL Id: hal$02017091-2019$ 